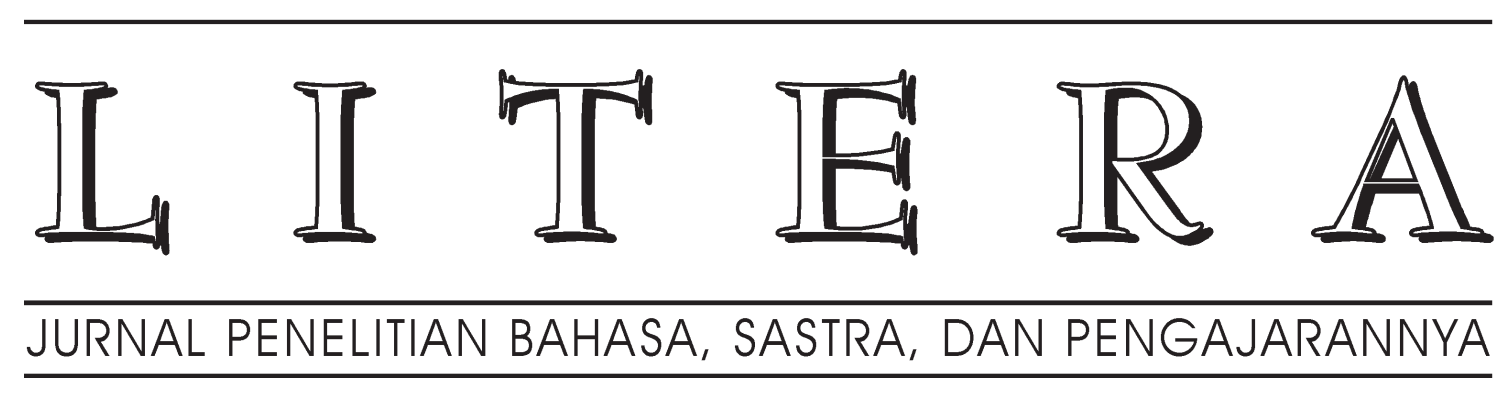

Berdasarkan SK Dirjen Dikti Nomor: 66b/DIKTI/Kep/2011, tanggal 9 September 2011 tentang Hasil Akreditasi Terbitan Berkala Ilmiah, LITERA dinyatakan sebagai Terbitan Berkala Ilmiah Terakreditasi, periode Agustus 2011 sampai dengan Agustus 2016 


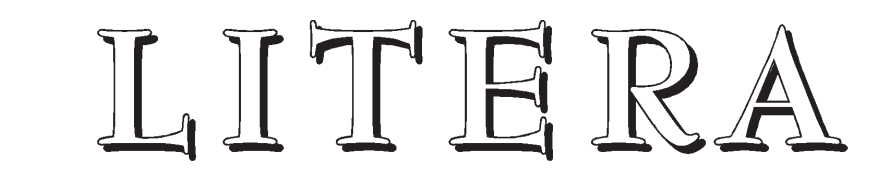

Jurnal Penelitian Bahasa, Sastra, dan Pengajarannya

Volume 12, Nomor 1, April 2013

* The Feminist Voice In Lucille Clifton's “The Thirty Eighth Year", "Miss Rosie”

27-38 and "Final Note To Clark"

Emilia Tetty Harjani 


\title{
THE FEMINIST VOICE IN LUCILLE CLIFTON'S THE THIRTY EIGHTH YEAR, MISS ROSIE AND FINAL NOTE TO CLARK
}

\author{
Emilia TettyHarjani \\ English Department STBA-LIA Yogyakarta \\ email: emil_harjani@yahoo.com
}

\begin{abstract}
This study is an analysis of three poems Thirty Eighth Year, Miss Rosie and final note to clark written by Lucille Clifton, a contemporary black American poet and writer. It intends to find out what the works articulate, showing the feminist voice. The analysis was conducted sociologically based on the selection criteria that they have the same theme as the common ground, and the data were collected through library research. The results show that the speakers of the poems articulate their consciousness of self-worth voicing basic feminist perspective against confining domestic life, white hegemonic beauty standard, and male role in black American household.
\end{abstract}

Keywords: feminist voice, self-worth, black American women, domestic life, white beauty standard, male role

\section{SUARA FEMINIS DALAM THE THIRTY EIGHTH YEAR, MISS ROSIE DAN FINAL NOTE TO CLARKKARYA LUCILLE CLIFTON}

\begin{abstract}
Abstrak
Penelitian ini menganalisis tiga puisi berjudul Thirty Eighth Year, Miss Rosiedan final note to clarkkarya Lucille Clifton, seorang penyair dan penulis kontemporer Amerika berkulit hitam. Penelitian ini bertujuan mengetahui apa yang disuarakan oleh karya-karya tersebut, yang mewakili suara feminis. Analisis ini dilakukan secara sosiologis dengan menggunakan kriteria pemilihan bahwa karya-karya tersebut memiliki tema dan landasan yang sama, dan data dikumpulkan melalui studi pustaka. Hasil penelitian menunjukkan bahwa tokoh dalam karya-karya tersebut menyatakan kesadaran akan harga diri untuk menyuarakan pandangan feminis dasar yang menentang kehidupan keluarga yang membelenggu, standar kecantikan kulit putih yang hegemonis, dan peran pria dalam rumah tangga Amerika kulit hitam.
\end{abstract}

Kata kunci: suara feminis, harga diri, wanita Amerika kulit hitam, kehidupan rumah tangga, standar kecantikan kulit putih, peran laki-laki

\section{INTRODUCTION}

For centuries, women have been regarded as inferior beings compared to men. The culture in the world, so far, is revealed to be patriarchal construction where males dominate and control the political, economic, social and even literary structures. They determine the social role, cultural and personal significance of women. Even the definition of what a woman is is established within the male socially and culturally constructed ideas. Consequently, women emerge as secondary, even nonexistent players in the major social institutions in the culture; for example in the government and educational systems. They appear to be "the second sex", or "the other", 
showing males' beliefs on women's inferiority - assumed as well and accepted unconsciously by women (Bressler, 1999: 181-185). Thus, for centuries, no equal opportunities and contribution in cultural systems have been demonstrated by the two sexes.

Feminism, existing in response to women-marginalizing social construction, is concerned with women's efforts to gain gender equality with men. It deals with women's empowerment, independence in choice making, and opportunity to get equal education and professions as men, making housewife-role not the only career a woman should pursue. Domestic life, in which women have to live as mothers and housewivesthe roles previously celebrated in the nineteenth century as parts of the cult of femininity, is presently viewed as a form of limiting and imprisoning women's life and expressions. Women should be liberated from oppressive, confining domestic life and other confining male ideas connected to women. They should get more chance for self-development and exercise their potential and talents in public career and life. These are the efforts to eliminate what Friedan called "segregation of sex roles" (Holinger and Capper, 2001: 387).

TheAmerican contemporary feminism, pioneered by Friedan in modern 1960s is termed 'white feminism' because it was originated from the struggle of white middle class women in white society, and it spoke for white middle class women to get gender equity with white men. Yet, it originally did not cover the problems faced by minority women, like black American women.

Black American women certainly have a unique experience, different from that of their white counterparts. Since their arrival to America, they had and have been a minority, living as slaves in the past and lower class mostly in the present America. Racial and gender discrimination was and is central to the life of black American women in the past and present. Consequently, black feminism is different from white feminism. Black feminism's struggle is more complicated than just against gender problem because it intersects race, gender, and class problems. Black American women's fight, thus, exists within the struggles against sexual, racial and class oppressions. It is due to the black American woman's existence as a woman (versus black and white men), as a black (versus white men and women), and her position in certain class in black and white society. So, it radiates out from just a gender struggle. Black feminist's purpose is fostering black women's empowerment and conditions of social justice. It fights against the mainstream's thought that black women are inherently inferior and urges them to forge self-definitions of selfreliance and independence (Collins, 2000: $x, 1,2)$. Complication of gender, race and class struggles, thus, characterizes black feminism.

Lucille Sayles Clifton is a contemporary black American female poet, born in 1936 in lower class family; however, she is well educated and is now teaching at University of California at Santa Cruz and American University in Washington, D.C and is presently Distinguished Professor of Humanities at St. Mary's College of Maryland. The success in literature also follows her success in career as she won many literary prizes and awards. (http:// www.english.illinois.edu/maps/poets/af/ clifton/about.htm., http://openvault.wgbh. org/ntw/MLA000368/index.html.)

Her works usually uncover the problems of being black Americans, especially those of African American women. Celebrations of black American ancestry, heritage and culture; appraisal to black Americans' resistance to oppression and their survival of economic and political racism; ethnic pride of womanish principles; virtue and dignity in the 
ordinary lives of black Americans would commonly be her themes in her works, be it a poem, short fiction or prose. (http:// www.english.illinois.edu/maps/poets/a_f/ clifton/about.htm. )

Lucille Clifton's three poems, "The Thirty Eighth Year" (1974), "Miss Rosie" (1980), and "final note to clark" (1993) are the examples of literary works voicing feminism of black American women. Basically, they do not show literal black American woman's struggles and fights against gender, race and class inequality. Therefore, there is curiosity on how the three poems voice feminist perspective. This study, then, intends to find out what is articulated in the three poems, that shows the black American women's feminist voice and how each of Lucille Clifton's three poems articulates the voice.

\section{Method}

As feminism perspective relates social condition, in analyzing the poems, sociological approach is used. Sociological criticism starts with the conviction that "the art's relation to society are vitally important, and that the investigation of these relationships may organize and deepen one's aesthetic response to a work of art. Art is not created in a vacuum; it is the work not simply of a person, but of an author fixed on time and space, answering to community of which he is an important, because articulate part" (Scott, 1962:123).

In this study, library research is carried out applying descriptive analytical methods. Data are collected from the primary - the three poems as well as the secondary sources such as books, essays, journals, and electronic data accessed through the internet. They are organized, classified and analyzed. The result is presented in the conclusion of the study.

\section{DISCUSSION}

The three poems present black American women as the speakers in the poems. They are depicted to be in different situation; the speaker in "The Thirty Eighth Year" is a black American woman who leads a domestic life, the one in "Miss Rosie" is a black American woman, relating herself to a white woman, showing her attitude towards white concept of beauty, the one in "final note to clark" is a black American woman in her relation to a black American man, showing gender problem in their family life.

\section{Domestic Life and Women}

The following is a brief account on the origin of the demeaning of domestic life and the women leading the profession, which originated from the white women history in the nineteenth century American industrial progress. Black American women shared the perspective that domestic life is confining in the modern era, long after the emancipation from slavery and the gain of civil rights. In American history and social life, the demeaning of domestic life and service starts from the emergence of industrial period in America.

Actually, woman's place had always been in the home, but during the preindustrial era or pre Civil War time, the economy itself had been centered in the home and its surrounding farmland. While men had tilted the land (often aided by their wives), the women had been manufacturers, producing fabric, clothing, candles, soap and practically all the other family necessities. Women's place had indeed been in the home-but not simply because they bore and reared children or ministered to her husbands' needs. They had been productive workers within the home economy and their labor had been no less respected than their men's. When manufacturing moved out of the home and into the factory, the ideology of womanhood began to raise the wife and mother as ideals. As workers, women had at least enjoyed economic 
equality, but as wives, they were destined to become appendages to their men, servants to their husbands. As mothers, they would be defined as passive vehicles for replenishment of human life (Davis, 1981: 32).

As the ideology of femininity $-\mathrm{a}$ by-product of industrialization - was popularized and disseminated through the new ladies' magazines and romantic novels, women came to be seen as inhabitants of a sphere totally severed from the realm of productive work. The cleavage between the home and public economy, brought on by industrial capitalism, established female inferiority more firmly than ever before. "Woman" became synonymous in the prevailing propaganda at the time with "mother" and "housewife," and both "mother" and "housewife" bore the fatal mark of inferiority (Davis, 1981: 12).

The cleavage between the new, capitalist economic sphere and the old home economic became ever more rigorous due to the revaluation of economic production. Factory-product commodities are regarded important because of their ability to generate profit. Since housework did not generate profit, domestic labor was naturally defined as an inferior form of work as compared to capitalist wage labor (Davis, 1981: 228)

Further, the countless chores collectively known as "housework" cooking, washing dishes, doing laundry, making beds, sweeping, shopping, etc. apparently consume almost half of average housewife's hours in a year. The burden is added with the constant and unqualifiable attention mothers must give for their children. However, her never-ending toil as a housewife rarely brings about expressions of appreciation within her family. 'Invisible', 'repetitive', 'exhausting', 'unproductive', 'uncreative' - are the expressions used to describe the nature of housework (Davis,
1981: 222). Consequently, domestic life is regarded as inferior and not meaningful, oppressive and confining for women as it does not allow them some self-expression and self-actualization.

\section{Discussion on "The Thirty Eighth Year"}

"The Thirty Eighth Year" is about a black American woman's consciousness on her confining domesticity which she finds unsatisfying and it presents the woman's determination to get out of the present domestic confinement and to explore her potentials to be a self in public life. The followings are the first two stanzas of the poems:

1) the thirty eighth year

of my life

plain as bread

round as cake

an ordinary woman.

2) an ordinary woman.

3) i had expected to be

smaller than this,

more beautiful,

wiser in afrikan ways,

more confident,

$i$ had expected

more than this.

(http://www.43things.com/entries/ view/160999.)

They give information on the speaker's condition. She is a thirty eight year old black American woman that leads the life like that of other ordinary women, that is, the domestic life of a housewife. The lines the thirty eight year of my life and as plain as bread implies that the speaker feels that her life is simple, not complicated and not decorated because her mobility and affairs are limited to the house she lives in. The house is probably the only place she does her activities and the household is the affair she has to handle and the only career she has. Interestingly, she relates her domestic life to her physical appearance 
to the typical appearance of a housewife that she is a fat woman and probably is not beautiful through the line as round as cake. So, she mentioned herself as an ordinary woman in terms of appearance as well as circle of life. She seems to feel very restricted to and suffocated in her limited circle and confining situation as she expects to be more than her present condition. Her expectation to be smaller, more beautiful, wiser in African ways and more confident signifies her dream of change. The next stanzas show her condition further.

3) i will be forty soon. my mother was once forty.

4) my mother died at forty four, a woman of sad countenance leaving behind a girl awkward as a stork. my mother was thick, her hair was a jungle and she was very wise and beautiful and sad.

5) i have dreams for my mama more than once. i have wrapped me in your skin and made you live again more than once $i$ have taken the bones you hardened and built daughters and they blossom and promise fruit like afrikan trees i am a woman now. an ordinary woman.

6) in the thirty eighth year of my life, surrounded by life, a perfect picture of blackness blessed, i had not expected this loneliness. (http://www.43things.com/entries/view/ 160999.)
By saying that she is going to be forty, she shifts talking about her mother who was once forty years old and died at the age. The mother is described as a wise, fat woman, with big hair; however, she is mentioned as a beautiful one, showing the pride in the original black American's standard of beauty. Yet, the speaker also states that she had sad countenance, showing that she was not happy in her life. It can be inferred that the mother represents the traditional, socially expected type of mother who is not happy with her condition. She was wise as a mother and was able to fulfill her duty and role as a housewife as her society expected her to be, but she was sad because she was not herself. She did not have self-actualization in public life as she lived only for her family. The speaker seems to realize this condition as she says "I have dreams for my mama more than once." Here, she expects that her mother was free from the burden of confining life and was able to reach her self-fulfillment. She regards herself as the reincarnation of her mother and the one who carries the mother's aspirations as she says " $i$ have wrapped in your skin and made you live again more than once and $i$ have taken the bones you hardened." These two women, the mother and the speaker, can be said to represent the ordinary women living in domesticity. And, the speaker wants them to have freedom to pursue self-fulfillment.

The presence of different generationsthe speaker's mother and daughters, besides showing her relation to other women in her family, also reflects the past, present, and future condition of black American women in terms of liberation from domesticity. So, it portrays gender problem within a certain race in different eras reflected through the presence of different generations of black American women. The daughters of the speaker represent liberated girls who have more chance to make their own decision and 
pursue public life, seen through the lines, and they blossom and promise fruit and like African trees. The speaker represents a woman in between the different eras. She, being a housewife and a mother like her mother, finds that being in domestic life is unsatisfying to her, as it is not her self-fulfillment. Although she is successful to be a 'perfect' housewife and a mother for her daughter, she is not happy and satisfied as she says "in thirty eighth, year of my life, surrounded by life, a perfect picture of blackness blessed, I had not expected this and loneliness" because her life as a housewife is not like what she expected before. She becomes like other ordinary women trapped in domesticity. "Loneliness" here reflects her domestic confinement or the probable result of living domestically. She expects to be more than she is now. She does not want to lead the life her mother led anymore.

Such desire or dream is understandable as some black American women view motherhood as a truly burdensome condition that stifles their creativity, exploits their labor, and makes them partners in their own oppression (Collins, 2000: 176) although in black American family culture and society, motherhood is an honorable status. Historically, motherhood has been a central importance in the philosophies of the people of African descent. Black American people tend to glorify motherhood. It leads to the persisting image of "super strong black mother". Yet, they refuse to acknowledge the issues faced by black American mothers who 'came back to the frequently thankless chores of their own loneliness, their own families (Collins, 2000: 174). In fact, glorification of motherhood and womanhood, which reflects society's respect on women and their roles, instead creates burdens to women through the society's expectation. At the end, it might exist as certain kind of 'oppression to women', creating some stresses and problems within the women. This is sometimes not acknowledged by the society.

The poem ends with the speaker's realization of her condition and the awareness of her self-worth so that she decides to change and pursue her aspiration in public life, which gives more self-fulfillment for her. This is obvious in the lines $i$ am the turning the final turn/into the shining dark, let me come to it whole, and not afraid, not lonely, out of my mother's life and into my own. The lines $i$ had expected more than this, $i$ had not expected to be and an ordinary woman indicates that she wants life that is not like ordinary women or housewives.

7) if it is western

if it is the final

europe in my mind

if in the middle of my life

$i$ am the turning the final turn

into the shining dark

let me come to it whole

and holy

not afraid

not lonely

out of my mother's life

into my own.

into my own.

8) i had expected more than this.

$i$ had not expected to be

an ordinary woman.

(http://www.43things.com/entries/view/ 160999.)

So, the poem presents woman's domesticity problem versus woman's desire or dream to be herself, free from family and race tradition and able to pursue what she wants. The content of the poem portrays women's problem that exists because of the conflict of a woman as a 'self and as a housewife (and a mother) whose 'self' is no longer hers but her family's and her society's. The 
woman's awakening on her self-worth and determination 'to lead her own life' underlies the feminist point.

\section{Black American Women and Standard of Beauty}

In fact, what and who are considered beautiful vary among cultures. Different cultures have different concept of beauty. Also, over time, the concept of beauty seems to fluctuate, sometimes favoring rather heavy individuals and at other times very skinny ones. In different cultures, parts of the body may be purposefully exaggerated in the name of beauty, the effects of which might even seem grotesque to those of another culture. For example, various tribes throughout the world use different methods to lengthen necks, exaggerate mouths, ears and even the shape of the head (http://www.touregypt. net/featurestories/beauty.htm.).

What remains consistent is that many notions of beauty are rooted in hegemonically defined expectations. In America, due to white American racism, that colors its history and permeates its culture, standard of beauty has become racially biased to the white hegemonic expectations. Contemporary image of an ideal woman is dominated by white standard; that an ideal woman should be white, slim, tall and blonde one from upper-class (Patton, 2006: 30, Wolf, 2004: 4).

Though there are varieties of beauty, the original concept of beauty of Africans tends to favor a black woman with heavy body with large hips and buttocks, dark skin, sensuous lips, dark eyes and curly hair (essaysbyekowa.com). (ekowa, 2002)

This hegemonic standard of beauty, thus, has already meant a marginalization of certain types of beauty. "The continuance of hegemonically defined standards of beauty in the United States, and the marginalization of certain types of beauty that deviate from the 'norm' are devastating to all women. Historically, the differences in body image, skin color, and hair haunt the existence and psychology of black women, especially since one common U.S societal stereotype is the belief that black women fail to measure up the normative standard" (Patton, 2006: 25). This only creates the inferior beauty of minority women, including black American women, whose physical appearance cannot meet the white "defined" standards.

\section{Discussion on "Miss Rosie"}

when I watch you

wrapped up like garbage

sitting, surrounded by the smell

of too old potato peels

or

when I watch you

in your old man's shoes

with the little toe cut out

sitting, waiting for your mind

like next week's grocery

I say

when I watch you

you wet brown bag of a

woman

who used to be the best looking gal

in Georgia

used to be called the

Georgia Rose

I stand up

through your destruction

I stand up

(http://project 1 .caryacademy. org/echoes/poet_Lucille_Clifton/ InspiredpoemsClifton.htm.)

"Miss Rosie" reveals a black American woman's dignity as the result of her consciousness of self-worth across racial boundary which is portrayed through the 'loss of beauty' and distressing physical deterioration of Miss Rosie, a white woman, because of aging. The essence of the poem is that woman's worth does not merely lie on beauty. The poet deliberately relates a black American woman to a white 
woman to emphasize the strength of the black American woman in the problem of gaining her consciousness of woman's worth in subordinating racial problem under the same sex. In the hierarchy of man and women in racial relationship, black American women may occupy the lowest rank as they are subject to racism by white men and women, and sexism by white and black American men. Gaining consciousness of self-worth is, thus, a tremendous and significant thing in black woman's life.

Miss Rosie used to be the most beautiful girl in Georgia, a Southern state, that she gained the title "Georgia Rose". Due to the white concept of beauty, it can be inferred that Miss Rosie was a beautiful, Caucasian girl with tall and slender body and blonde hair. The title also shows how people adored her in her youth because of her beauty. This somehow reflects Miss Rosie's achievement physically. Meanwhile, the word "Miss" used by the speaker gives an idea on the position of the speaker as a black American girl and Rosie as a white girl that Miss Rosie was probably an upper class girl, and the speaker occupied socially more inferior position, probably, of lower class.

However, the present Rosie is strikingly different from Rosie in the past. She is an old white woman seen through the phrases your old man and sitting, waiting for your mind. Her old husband and slowness of mind indicate that she is old now. That she lives in poverty is shown through the phrases wrapped like garbage, in your old man's shoes and with the little toe cut out and that she is confined in domestic life as a housewife through the phrases sitting, surrounded by the smell and of too old potato peels. The phrase 'old potato' here indicates kitchen life.

The presence of beautiful Miss Rosie in the past and the old 'ugly' Miss Rosie in the present signifies the loss of beauty power to subdue men and of physical strength of a young woman, emphasizing on the uselessness of Miss Rosie now. Beauty is a significant factor for women to make relationship with men. It is woman's power to get man's power through marriage. Within racial relationship, white beauty is the 'supreme' used as the standard of beauty. However, the poem reveals that this beauty is no longer a significant thing any more as physical deterioration destroys it. So, basically Miss Rosie has nothing to be proud of.

The poem presents a black American woman's inner strength to get the essence of this distressing scene that enables her to see that woman's worth does not lie on 'beauty' solely as age will destroy it anyway. The poem, finally, reveals a black American woman's dignity, pride and courage in dealing with beauty and physical deterioration problems, which can be seen in the lines I stand up, through your destruction, and I stand up). How the black American woman is able to stand over the white woman can also be seen in the destruction of the white woman in terms of social class. From a beautiful upper class girl, Miss Rosie is depicted to be an ugly woman living in poverty. The use of' ' $\mathrm{I}$ ' in capital letter (which is not found in other two poems discussed) also shows the strong dignity and the pride in the black American woman, signifying that the black woman is worthy as a woman.

\section{Black American Men and Manhood}

The existing culture, including the traditional role of man and woman in a family, is patriarchally constructed. According to the traditional family structure, which is based on the patriarchal system, ideally a husband or father is a strong figure in the family. Sometimes, he is also a dominating and leading figure over his wife and children. He also serves the role of a breadwinner and protector of his family. The role a man plays in his family more or less reflects his manhood. 
However, many black American husbands and fathers fail to perform their role according to the long established standards expected of husbands and fathers in American society (Thompson: 1974: 91). Often, slavery practice is blamed for the deficiency of men's role in black families as it has already usurped the black American manhood. Throughout more than 200 years of slavery, black American fathers and their families were regarded as mere chattel. The existence of black family institutions under the white ones and slavery itself had made the black fathers and husbands lose their power over their own families because they could no longer protect their families as they could be completely and permanently separated from families at the pleasure of their masters; also to be the breadwinner of them because everything came from their masters. Thus, slave masters had usurped the traditional role of the father as the sole provider and protector of the black family (Thompson, 1974: 91), making them unable to assume any significant family responsibilities.

In the present time, the deficiency of manhood is obvious in the psychological problem faced by black American men. They suffer the syndrome of invisibility within their family and social life due to racial discrimination. Invisibility is "an inner struggle with the feeling that one's talents, abilities, personality and worth are not valued or recognized because of prejudice and racism." Conversely, one feels visible when his talents, abilities, personalities, and worth are respected (Franklin, 2004: 4). Racism has proven to create problems in black Americans' daily life starting from problems of acceptance in work place, in social circles and in educational institutions such as universities, difficulties in promotion and getting wage raise. So, "invisibility" is burdensome to black American men because it implies that "they have been tricked, deceived, or compromised into humiliation, disgrace, or victimization" (Franklin, 2004: 5). This certainly hinders black American men to move forward.

The relationship between black American men and women also seems to be problematic. Historically, the personal and intimate relation between black American men and women dates back to Africa where there were clearly defined, traditional roles for men and women. These roles were obliterated by the cruel economics of slavery. In slavery, "there was equality in the physical abuse and psychological havoc wreaked upon black men and women. Out of this cauldron new gender roles emerged. Black men and women in captivity had to invent and then employ altogether new ways of relating to one another, and new strategies to protect each other, to survive the devastating humiliation and brutal physical assault delivered by pernicious business of slavery" (Franklin: 2004: 142). As the oppression of women was identical to the oppression of men, black American women appeared to be 'genderless" as both the men and women served to be means to gain profit to the owners. Judged by the evolving nineteenth century ideology of femininity, which emphasized women's roles as nurturing mothers and gentle companions and housekeepers for their husbands, black American women were practically anomalies. Meanwhile, the slave system discouraged male supremacy within black American men. They could not appear to be family head at all. As a result, because of the struggles against the racially and sexually abuse in slavery, most black American women have emerged as stronger women compared to the white counterparts, even to their men.

In the mean time, present black American men show peculiar behavior because of their view and difficulty to built relationship or family with their women. 
Black American men regard the women, especially those who meet female beauty criteria based on European standards and who other black American men consider good looking and desirable, as "trophies" that are worth adored and fighting for. Gaining such women means gaining status among black men (Franklin, 2004: 144, 145). Even, being labeled a "ladies man" or "womanizer," implies high status and expert skill for black American men. This in fact constitutes their effort to gain visibility.

However, for many black American men, it is difficult to remain in the relationship once it is secured because the conquest of the women was very often sole motivation. Among black American men there exists little or no conversation when they gather and talk about purpose, role, and skills required of a proper partner in a relationship after it has been established. Commitment, thus, feels like a trap for them. That's why many black American women regard that it is difficult for black American men to have serious discussions with them and to ask for their commitment.

\section{Discussion on "final note to clark"}

they had it wrong,

the old comics.

you are only clark kent

after all. oh,

mild mannered mister,

why did i think you could fix it?

how you must have wondered

to see me taking chances,

dancing on the edge of words,

pointing out the bad guys,

dreaming your $\mathrm{x}$-ray vision

could see the beauty in me.

what did i expect? what

did i hope for? we are who we are,

two faithful readers,

not wonder woman and not superman.

(http://www.math.buffalo.edu/ sww/

clifton/poems-LC.html\#lc3.)
"Final note to clark" presents a black American woman's realization on the ordinariness of her man and on gender equality. Yet, at the same time it also presents the strength of a black American woman in dealing with life. It shows the relationship of male and female black Americans within their own racial circle. The woman is independent enough to pursue public life; thus, she is emancipated already. However, she is disappointed because her man is a weak and irresponsible one. She has to go outside home to work because she has no choice. Thus, her going out of the house for a job is in fact oppression to the woman because there is no equal contribution to the family.

The poem begins with gender disappointment of a black American woman over her man who does not perform his 'supposed to be' role. She put high expectation and somehow adored him at first, before she finds out who he really is.

Interestingly, the speaker compares the black American man's condition to the two sides of Superman's lives to portray her disappointment. Superman carries the images of physically strong, kind-hearted, protective, and man-serving savior with super power, such as $\mathrm{X}$-ray vision, freezing breath, burning laser vision. In short, he is an ideal image of man. Yet, Superman in ordinary life is Clark Kent. He disguises himself as an ordinary man hiding all his potentials or power even presenting himself as a weak clumsy one. The black American man in the poem is similar to Superman in disguise. He has potentials but he never exercises and uses them. The main reasons are probably that he does not know how to do it due to the historically lack of role model of black manhood in black American family and probably he suffers the invisibility syndrome, that commonly happens to most black American men. These are what sometimes 
create problems within black American family and perpetuate the stereotype of 'weak' black American men.

The women's disappointment in the poem is due to the fact that her husband is not like what she expects. He is a 'weak' husband, and is not as 'strong as he seemed to be'. He is far from her expectation. He is not a Superman; he is only a Clark Kent, as she says, "you are only clark ken and mild mannered mister. Worse than that, as reflected in the line "why did $i$ think you could fix it "her man is the Clark Kent who cannot transform to be Superman. The lines how you must have wondered, to see me taking chance, dancing on the edge of words, pointing out the bad boys show her former belief on his ability to transform to be a 'real man' so that she chose him, ignoring other people's bad opinion about him. 'The bad boys' here refer to the people's bad remark and opinion about him concerning his weakness in manhood.

Besides, her man is a man who is not able to appreciate her efforts for family maintenance and her creativity that characterizes individual's 'self' or potentials. This 'self' and her potentials are what the woman identifies as 'beauty'. But, her Clark Kent husband fails to see and does not admit this beauty in his wife, resulting in his wife's frustration. The expectation is apparent in the lines "dreaming your $x$-ray vision and could see the beauty in me." The sentences what did $i$ expect? and what did i hope for? refer to the angry expressions of the woman, indicating the woman's frustration on her husband's failure too see her and her potentials. The poem ends in the emphasis on the ordinariness of human beings, men and women, reflected through "we are who we are, two faithful readers, and not wonder women and not superman. This ordinariness, in fact conveys the self-worthiness of the woman as a strong individual in her relation with her man. Finally, how the name clark kent is written in small letters can also be interpreted as the 'weak' position of the man.

\section{CONCLUSION}

To sum up, Lucille Clifton's poems, "The Thirty Eighth Year","Miss Rosie", and "the final note to clark", voice black feminism. They do not show literal black American women's struggles and fights against racial and gender inequality, but they show feminist perspectives as they present black American women's consciousness of their "selves" which shows their self-worth across gender, class, and race. It is the self-worth that functions as the basis for the equity and characterized the feminist voice in the poems. In addition, all of the poems, in fact, share something in common that they begin with women's sex and race intertwining problems and end in women's self-consciousness and selfdignity as the resolution.

Lucille Clifton has given examples of social problems that might happen to and demean women, resulting in women's inferior feeling. Yet, she emphasizes that women's response i.e. viewing that their selves are worthy would play an important role in empowering themselves to solve their problems.

The writer of this study owes gratitude to Kenneth Hall, $\mathrm{PhD}$, a Fullbright visiting professor at Gadjah Mada University for introducing her to Lucille Clifton's poems; this has initiated the research on the three poems.

\section{REFERENCES}

Bressler, Charles. E. 1999. Literary Criticism. An Introduction to Theory and Practice. New Jersey: Prentice Hall, Inc.

Collins, Patricia Hill. 2000. Black Feminist Thought. New York: Routledge.

Clifton, Lucille. "final note to clark." (http://www.math.buffalo.edu/ sww/ 
clifton/ poems-LC.html\#lc3. June 4, 2009. 10.47)

Clifton, Lucille. "Miss Rosie." (http:// project 1 .caryacademy.org/ echoes/ poet_Lucille_Clifton/ InspiredpoemsClifton.htm. June 4, 2010. 10.28)

Clifton, Lucille. "The Thirty Eighth Year." (http://www.43things.com/ entries/ view/160999. 21 May 2010. 13:58)

Davis, Angela. 1981.Women, Race, and Class. New York: Random House.

Ekowa. "Lips, Hips and Finger Tips". 2002. (http://www.essaysbyekowa. com/ lis\%20hips\%20redux.htm). 6 Mei 2010.

Franklin, Anderson J. 2004. From Brotherhood to Manhood. How Black men Rescue Their Relationship and Dreams From the Invisibility Syndrome. New Jersey: John Wiley \& Sons, Inc.
Hollinger, David A. and Charles Capper (eds). 2001. The American Intellectual Tradition. New York: Oxford University Press.

Patton, Tracey Owens. Summer 2006; 18, 2. “Hey Girl, Am I More than My Hair? African American Women and Their Struggle with Beauty, Body Image and Hair." NWSA Journal; ProQuest Sociology.

Scott, Wilbur S. 1962. Five of Literary Aproaches. New York: Collier Books.

Thompson, Daniel C. 1974. Sociology of the Black Experience. Connecticut: Greenwood Press.

Trotter, Jr, Joe William. 2001.The African American Experience. Boston: Houghton Mifflin Company.

Wolf, Naomi. 2004. Mitos Kecantikan. Kala Kecantikan Menindas Perempuan. Yogya: Penerbit Niagara. (translated from The Beauty Myth. How Images of Beauty are Used Against Women. 2002. New York: Perennial). 